\title{
Extremely low-frequency electromagnetic fields cause DNA strand breaks in normal cells
}

\author{
Cosmin Teodor Mihai ${ }^{1 *}$, Pincu Rotinberg${ }^{2}$, Florin Brinza ${ }^{3}$ and Gabriela Vochita ${ }^{2}$
}

\begin{abstract}
Background: Extremely low frequency electromagnetic fields aren't considered as a real carcinogenic agent despite the fact that some studies have showed impairment of the DNA integrity in different cells lines. The aim of this study was evaluation of the late effects of a $100 \mathrm{~Hz}$ and $5.6 \mathrm{mT}$ electromagnetic field, applied continuously or discontinuously, on the DNA integrity of Vero cells assessed by alkaline Comet assay and by cell cycle analysis. Normal Vero cells were exposed to extremely low frequency electromagnetic fields ( $100 \mathrm{~Hz}, 5.6 \mathrm{mT}$ ) for 45 minutes. The Comet assay and cell cycle analysis were performed 48 hours after the treatment.

Results: Exposed samples presented an increase of the number of cells with high damaged DNA as compared with non-exposed cells. Quantitative evaluation of the comet assay showed a significantly $(<0.001)$ increase of the tail lengths, of the quantity of DNA in tail and of Olive tail moments, respectively. Cell cycle analysis showed an increase of the frequency of the cells in S phase, proving the occurrence of single strand breaks. The most probable mechanism of induction of the registered effects is the production of different types of reactive oxygen species.
\end{abstract}

Conclusions: The analysis of the registered comet indices and of cell cycle showed that extremely low frequency electromagnetic field of $100 \mathrm{~Hz}$ and $5.6 \mathrm{mT}$ had a genotoxic impact on Vero cells.

Keywords: ELF-EMF, $5.6 \mathrm{mT}$ and $100 \mathrm{~Hz}$, Continuous and discontinuous exposure, Comet assay, Cell cycle analysis, DNA damage

\section{Background}

The extremely low frequency electromagnetic fields (ELFEMF) are omnipresent in human life, being generated by common appliances electrical conductors that cross the populated areas or the walls of houses, medical devices used in the treatment of different illness, electrical cars (used in the public transportation systems or as private cars) and electrical trains (underground or suburban electrical trains). Both in the case of the medical devices (mainly used in the physiotherapy) and of the electrical components of the cars and trains, the common generated frequency is that of $100 \mathrm{~Hz}$ [1]. Even though the patients or passengers are exposed for a short time, the deserving personnel are subject to prolonged exposure. Also, the combined treatment of $100 \mathrm{~Hz}$ magnetic field and X-rays has increased the survival time of hepatoma implanted Balbc mice as compared to magnetic field or

*Correspondence: mihai.cosmin.teo@gmail.com

1 Department of Biology, "Alexandru loan Cuza" University of lasi, lasi, Romania Full list of author information is available at the end of the article
X-rays treated groups [2], suggesting the possible use in oncotherapy.

The exposure of different cell lines or organisms to electromagnetic fields have produced a bulk of data that were sometimes contradictory and didn't allow a concise and clear conclusion about the effects of electromagnetic fields on biological systems $[3,4]$. The International Agency for Research on Cancer (IARC) has evaluated the scientific data and has classified ELF magnetic fields as being "possibly carcinogenic" to human [5]. The worrying but contradictory epidemiologic or experimental data about the possible genotoxic effects of this kind of electromagnetic fields, suggesting the possible carcinogenetic effect, requires an enrichment of the pool of experimental information and the deciphering of its action mechanisms.

Carcinogenic processes have three developmental stages: initiation, promotion and progression. The first stage, tumour initiation, begins when the DNA in a cell or population of cells is damaged by exposure to exogenous or endogenous carcinogens. If this damage is not repaired, 
it can lead to genetic mutations. The responsiveness of the mutated cells to their microenvironment can be altered and may give them a growth advantage relative to normal cells [6-9].

The possible carcinogenetic effect of the low frequency and intensity electromagnetic fields are still under debate, the data being controversial. Studies in this field suggested that exposure to low frequency and intensity electromagnetic fields could alter the DNA integrity, which could trigger the initiation of carcinogenetic processes or could accelerate the development or spreading of already present cancers $[10,11]$. Also, it was suggested that chronic exposure to the ELF-EMF could be involved in the development of some neurodegenerative diseases by production of reactive oxygen species [12]. Contrary, other researches identified no effects on the integrity of the DNA in the conditions of exposure to the electromagnetic fields [13-17].

The aim of the study was to test if, in effect, there are any differences between continuous or discontinuous extremely low frequency electromagnetic fields on the DNA integrity of normal Vero cells, in order to evaluate the possible disruptions that could lead to mutagenicity. The evaluation of the effects of the extremely low frequency electromagnetic fields was assessed by alkaline comet assay and cell cycle analysis.

\section{Methods}

\section{Cell cultures}

Vero cells (ECACC 88020401) are adherent to substratum with a fibroblast-like morphology. The cells were cultivated in a DMEM medium (Dulbeco's Modified Eagle's Medium, Biochrom AG, Germany, FG 0415), supplemented with $2.0 \%$ foetal bovine serum (Sigma, Germany, F9665) and $100 \mu \mathrm{g} / \mathrm{mL}$ streptomycin (Biochrom AG, Germany, A 331-26), $100 \mathrm{IU} / \mathrm{mL}$ penicillin (Biochrom AG, Germany, A 321-44). The cell cultures were seeded at a density of $5 \times 10^{5}$ cells in $25 \mathrm{~cm}^{2}$ flask (TPP Techno Plastic Products AG, Trasadingen, Switzerland) and maintained in a $\mathrm{CO}_{2}$ incubator (Binder $\mathrm{CB}$ 150, Tuttlingen, Germany), at $37^{\circ} \mathrm{C}$. When the cells reached confluence in the monolayer stage, the cultures were divided into control and electromagnetic treated cell cultures.

\section{ELF-EMF exposure setup}

The setup for electromagnetic exposure consisted in a Helmholtz pair of coils connected in parallel to a magnetodiaflux (IBF, Romania) device, that generates a pulse electromagnetic field (PEMF) having a frequency of 100 pulses/second.

The $29 \mathrm{~cm}$ diameter coils were made of copper wires with 620 turns. The coils were set at a distance equal with their radius $(14.5 \mathrm{~cm})$ which assured a central homogeneous magnetic field $(5.6 \mathrm{mT})$. The unpowered coils presented a magnetic field with a $0.021 \mathrm{mT}$ intensity, similar to the registered magnetic field background. The magnetodiaflux device delivered to the two coils a pulsating direct current (PDC), obtained by converting and rectifying the $220 \mathrm{~V} / 50 \mathrm{~Hz}$ alternative current. The PDC had a $100 \mathrm{~Hz}$ frequency and the peak voltage variation, measured with an oscilloscope (Tektronix, Guernsey, Channel Islands), was of 42 volts and 2.0 Ampers.

The coils were housed in the cell incubator, the temperature being constant and uniformly distributed all the time of the exposure $\left(37 \pm 0.2^{\circ} \mathrm{C}\right)$, as monitored by a thermocouple thermometer (Hanna Instruments, Italy). The homogeneity of the magnetic field produced by the coils in the area of exposure is shown in the Figure 1, image being generated by Vizimag ver.3.193 software (๑J. Beeteson 1999-2009, shareware version), using the provided characteristics of the coils and current.

The experimental conditions used for the treatment of the Vero cells (frequency of $100 \mathrm{~Hz}$ and intensity of $5.6 \mathrm{mT}, 45$ minutes) were chosen on the basis of the common parameters used in physiotherapy and by those generated by electrical cars and trains. Also, the similar exposure conditions has conducted to reduction of the tumor development when were applied in combination with oncochemotherapy [18].

\section{Magnetic flux density measurement}

The magnetic flux density measurement inside of Helmholtz coils system was performed using LakeShore 421 Gaussmeter, having valid NIST certificates. Both axial and transverse probes were used for the measurements. Before the measurement process, each probe was calibrated in a zero-field chamber. For the characterization of the uniformity in the samples volume, experimental measurements and software simulation were used. The measurements were performed in equidistantly distributed points inside of coils. In each point, axial (using axial probe) and radial (using transverse probe) values of the magnetic flux density were tested. The experimentally detected values were compared to the calculated ones.

The field lines distribution and the magnetic induction values in the centre of the coils system were calculated using a Vizimag ver.3.193 software. In Figure 1, the field lines distribution and the field lines density for our coils are presented. The experimental measured values of the magnetic flux density are in good accordance with calculated ones. The conclusion is that the whole volume of cell culture container is subjected to a uniform magnetic induction value. The low values of magnetic susceptibility of the biological samples ensure a uniform value of the magnetic field inside the container volume. 

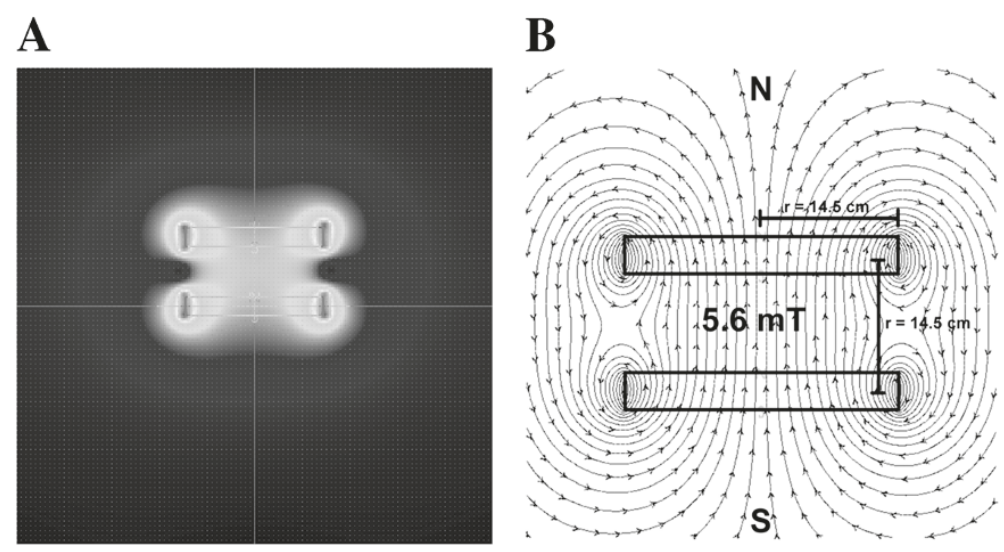

Figure 1 Magnetic flux density (A) and flux lines distribution (B). Magnetic flux density and flux lines distribution in the area of exposure of the cells when the Helmholtz coils were powered with a direct current with the frequency of $100 \mathrm{~Hz}$ and an intensity of 2.0 Amperes.

\section{Treatment of the cells}

The cell culture flasks with the cells were placed in the central region of the Helmholtz coils, perpendicular to the magnetic field lines. The cells were exposed once for 45 minutes and were returned to the incubator after the treatment. The exposure of the cells was performed in a continuous (cEMF, permanent exposure to the magnetic field during the 45 minutes of the treatment) or in a discontinuous manner (dcEMF, cycles of one second on and three seconds off). Sham-exposed cells were put into the same experimental conditions as the treated samples but without energizing the coils, the EMF background remaining practically unchanged.

To asses the late effects of the exposure to ELF-EMF, the culture flasks were returned to the incubator and maintained for another 48 hours after the evaluation of DNA integrity by alkaline Comet assay and cell cycle analysis were performed.

\section{Comet assay analysis}

We followed the technique described by Ostling and Johanson [19] with minor modifications by Singh et al. [20], as presented in [21].

The $50 \mu \mathrm{L}$ of ELF-exposed and the sham-exposed cells (20,000 cells) were mixed with $150 \mu \mathrm{L}$ of low-melting agarose $\left(0.8 \%, 37^{\circ} \mathrm{C}\right)$, and this cell suspension was pipetted onto $1 \%$ normal-melting agarose pre-coated slides, spread with a cover slip, and kept on a cold flat tray for approximately 10 minutes to solidify.

The slides were then immersed in freshly prepared cold lysis solution $(2.5 \mathrm{~mol} / \mathrm{l} \mathrm{NaCl}, 100 \mathrm{mmol} / \mathrm{l} \mathrm{Na} 2$ EDTA, 10 $\mathrm{mmol} / \mathrm{l}$ Tris, $\mathrm{pH} 10,1 \%$ sodium sarcosinate, $1 \%$ Triton $\mathrm{X}-100,10 \%$ DMSO, $\mathrm{pH} 10$ ) and lysed overnight at $4^{\circ} \mathrm{C}$. Subsequently, the slides were drained and placed in a horizontal gel electrophoresis tank, side by side and very close to the anode. The tank was filled with fresh electrophoresis buffer ( $1 \mathrm{mmol} / \mathrm{l} \mathrm{Na}{ }_{2}$ EDTA, $300 \mathrm{mmol} / \mathrm{l}$ $\mathrm{NaOH}, \mathrm{pH}>13$ to a level approximately $0.4 \mathrm{~cm}$ above the slides. The slides were left in the solution for 40 minutes, to allow equilibration and unwinding of the DNA before electrophoresis. The electrophoresis was conducted at $25 \mathrm{~V}, 300 \mathrm{~mA}, 4^{\circ} \mathrm{C}, 20 \mathrm{~min}$, field strength $0.8 \mathrm{~V} / \mathrm{cm}$. All steps were performed under dimmed light to prevent the occurrence of additional DNA damage. After electrophoresis, the slides were washed three times with Tris buffer $(0.4 \mathrm{~mol} / \mathrm{l}$ Tris, $\mathrm{pH} 7.5)$, to be neutralized, then air-dried and stored until needed for analysis. Comets were visualized by ethidium bromide staining $(20 \mu \mathrm{g} / \mathrm{ml}$, $30 \mathrm{~s}$ ) and examined at 200 magnification with a fluorescence microscope (Nikon Eclipse 600, Nikon corp., Japan).

\section{Image analysis of comets}

The image analysis was performed with CASP software (CASP or Comet Assay Software Project, http://www. casp.sourceforge.net). The evaluation of comets was done by tail length, \% content of DNA in tail and by calculating tail and Olive moment $[22,23]$.

\section{Cell cycle analysis}

After the electromagnetic treatment cells were harvested from the surface of culture flasks by trypsinization, they were resuspended in a complete medium and then pelleted by centrifugation. The cells were washed twice in cold PBS (Phosphate Buffered Saline). The cell pellet was resuspended in NIM-DAPI (Nuclear Isolation Medium DAPI, 4,6-diamidino-2-phenylindole, Beckman Coulter, USA) and were stained overnight at $4^{\circ} \mathrm{C}$. For every control and treated sample, 20.000 cells were measured on flowcytometer, using a $100 \mathrm{~W}$ mercury arc lamp, a 355/37 exciter and a $460 \mathrm{BP}$ filter for the collection of fluorescence and linear amplification. 
Table 1 Absolute frequencies of Comet types specific to control and exposed samples

\begin{tabular}{|c|c|c|c|c|c|}
\hline & \multirow{2}{*}{$\frac{\text { Control }}{\% \text { Mean } \pm \text { SEM }}$} & \multicolumn{2}{|c|}{ cEMF $100 \mathrm{~Hz}$} & \multicolumn{2}{|c|}{ dcEMF $100 \mathrm{~Hz}$} \\
\hline & & $\%$ Mean \pm SEM & $p$ & $\% M e a n \pm S E M$ & $p$ \\
\hline $\mathrm{A}(<5 \%)$ & $59.71 \pm 0.10$ & $55.83 \pm 0.08$ & $<0.002$ & $66.11 \pm 0.07$ & NS \\
\hline $\mathrm{B}(5-20 \%)$ & $24.82 \pm 0.49$ & $21.80 \pm 0.34$ & $<0.001$ & $8.61 \pm 0.81$ & $<0.001$ \\
\hline$C(20-40 \%)$ & $10.79 \pm 1.01$ & $9.59 \pm 0.83$ & $<0.001$ & $8.61 \pm 1.00$ & $<0.001$ \\
\hline$D(40-95 \%)$ & $4.68 \pm 1.81$ & $12.22 \pm 1.29$ & $<0.02$ & $16.11 \pm 1.43$ & $<0.05$ \\
\hline$E(>95 \%)$ & $0.00 \pm 0.00$ & $0.56 \pm 0.01$ & $<0.001$ & $0.56 \pm 0.00$ & $<0.001$ \\
\hline
\end{tabular}

Errors indicate the standard error of the mean (SEM) for $n=3$ independent experiments.

\section{Statistical analysis}

All of the experiments were carried out with at least three independent repetitions and all data were expressed as the mean value and standard error of mean (SEM). The statistical analysis was performed using Student's "t" test and the differences were expressed as significant at the level of $\mathrm{p}<0.05$.

\section{Results and discussion}

The qualitative analysis of the cellular damage determined by electromagnetic fields was evaluated by the extent of the damage and graded according to [21], the results being presented in Table 1 . The number of the cells that presented DNA damage higher than $40 \%$ was greater in the case of the cells subjected to the electromagnetic field treatment, compared to the control group. dcEMF had a more negative impact upon the integrity of the genetic material of Vero cells as compared to cEMF. In both cases, the differences were significant $(<0.05)$.

The quantitative evaluation was based on four parameters: tail length (TL), \%DNA in tail (TD), tail moment (TM) and Olive tail moment (OTM), the results being included in Table 2. The tail length gives us information about the dimension of DNA fragments (smaller fragments, longer tail) and it is expected to be proportional to the extent of DNA damage. As shown in Figure 2, the cEMF and dcEMF determined an increase of the tails in treated cells, the values of tail length being 1.65 (54.20 $\mu \mathrm{m} \pm 2.34)$, respectively $1.51(49.63 \mu \mathrm{m} \pm 3.23)$ times bigger than in the case of the control group (32.81 $\mu \mathrm{m} \pm 2.01)$. The differences between the treated and the control samples, evaluated by t test, were found to be statistically significant $(<0.001)$. The second parameter taken into consideration in the evaluation of the effects of the electromagnetic fields upon the integrity of the DNA of Vero cells was \%DNA in tail, which provides data about the damaged DNA content in individual cells, measured as the total intensity of ethidium bromide in every cell subjected to the electrophoresis in alkaline conditions. The \%DNA in tail increased significantly $(<0.001)$ in the cells exposed to the cEMF $100 \mathrm{~Hz}(13.37 \% \pm 0.88)$ and respectively to dcEMF $100 \mathrm{~Hz}(13.87 \% \pm 1.17)$, when compared to the control group $(8.8 \% \pm 0.78)$, the values being of 1.52 and 1.58, respectively, times bigger than the control value. The calculated parameters tail moment and the Olive tail moment correlate the extent of the tail with the quantity of DNA present in tail.

The tail moment represents the product of the tail length (also called the tail extent) and the percentage of DNA in the tail. EMF treatment determined an increase of TM $(17.40 \mu \mathrm{m} \pm 1.54$ for $\mathrm{cEMF}$ and $20.77 \mu \mathrm{m} \pm 2.16$ for dcEMF) as compared to the control group $(8.26 \mu \mathrm{m} \pm 1.03)$. The olive tail moment is calculated as a product of two factors: the percentage of DNA in the tail and the distance between the intensity centroids of the head and the tail along the $\mathrm{x}$-axis of the comet. OTM incorporates a measure of both the smallest detectable size of migrating DNA (reflected in the comet tail length) and the number of relaxed/broken pieces (represented by the intensity of DNA in the tail). As in the case of the other parameters, OTM has increased both in the case of cEMF (12.30 $\mu \mathrm{m} \pm 0.91)$ and of dcEMF (12.70 $\mu \mathrm{m} \pm 1.20)$ when compared with the control group $(6.58 \mu \mathrm{m} \pm 0.66)$, the calculated differences being statistically significant.

Table 2 Impact of the ELF-EMF on comet assay indices (TM and OTM) in Vero cell line

\begin{tabular}{lcccc}
\hline & \multicolumn{2}{c}{ Tail moment } & & Olive tail moment \\
\cline { 2 - 3 } & Mean $(\boldsymbol{\mu} \mathbf{m}) \pm$ SEM & $\mathbf{p}$ & Mean $(\boldsymbol{\mu} \mathbf{m}) \pm$ SEM & p \\
\hline Control cells & $8.26 \pm 1.03$ & - & $12.30 \pm 0.66$ & - \\
\hline $100 \mathrm{~Hz}$ cEMF & $17.40 \pm 1.54$ & $<0.001$ & $12.70 \pm 1.20$ & $<0.001$ \\
\hline $100 \mathrm{~Hz} \mathrm{dcEMF}$ & $20.77 \pm 2.16$ & $<0.001$ & $<.001$ \\
\hline
\end{tabular}

Errors indicate the standard error of the mean (SEM) for $n=3$ independent experiments. 

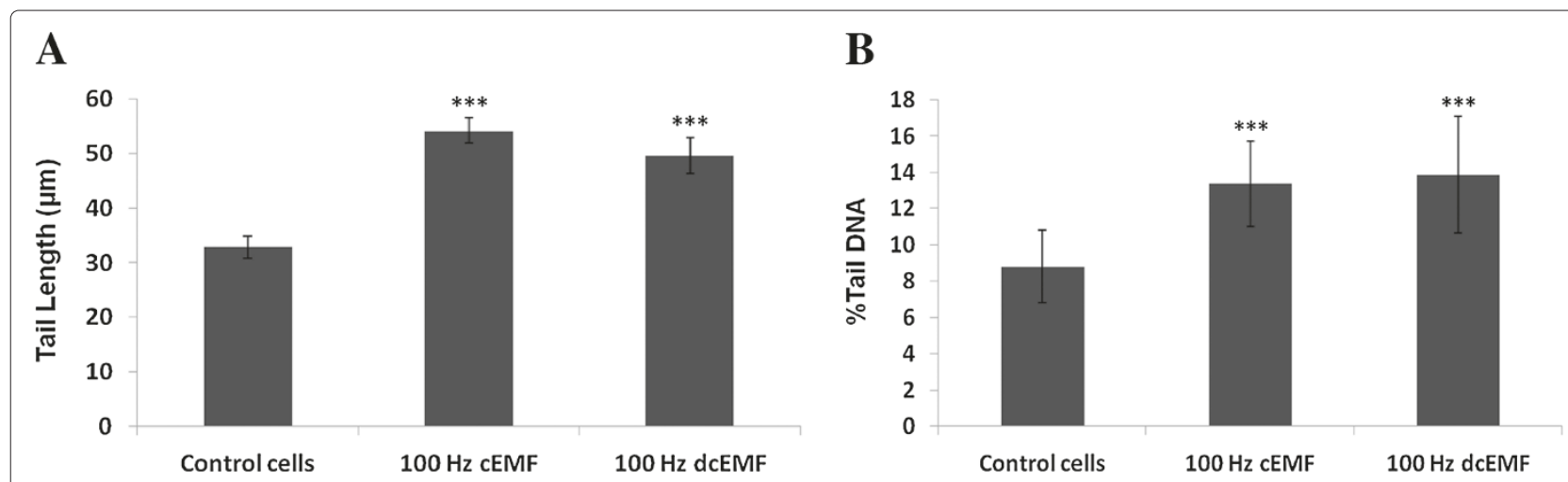

Figure 2 Tail length (A) and \% content in DNA (B). Tail length (left figure) and \% content in DNA (right figure) of the tail determined in Vero cells at 48 hours after the exposure to extremely low frequency electromagnetic fields $\left(100 \mathrm{~Hz}, 5.6 \mathrm{mT}, 45\right.$ minutes). ${ }^{* *}=<0.001$.

The registered values of OTM for cEMF and dcEMF were similar, with a small increase in the case of dcEMF.

Compared to controls, ELF-EMF-exposure caused a blockage of the cells in the $S$ stage of the cell cycle. After 48 hours, the highest percentage of cells blocked in the $\mathrm{S}$ phase was registered in the case of cEMF followed by dcEMF, as it can be seen in Table 3 . The general assumption is that extremely low frequency electromagnetic fields aren't genotoxic and do not affect the integrity of the DNA molecule, but the scientific data are still controversial and supplementary evidence is necessary to consider this physical agent as a real carcinogenic factor.

Other aspects that need to be clarified are the differences either in effect or in the magnitude of the effect, in respect to the use of continuous and intermittent electromagnetic fields. Ivancsits $[21,24,25]$ reported that intermittent electromagnetic fields caused DNA damage of the human diploid fibroblasts, while continuous electromagnetic field did not alter the DNA integrity. Starting from this experiment, Crumpton [26] argued that supplementary data, obtained in independent experiments, concerning the biological effects of low frequency electromagnetic, is necessary, and the link between electromagnetic fields and initiation of the carcinogenesis processes has to be proved.

The current study was designed to establish whether $100 \mathrm{~Hz}$ extremely low-frequency electromagnetic fields affect the DNA integrity in the normal Vero cell line, the DNA damage being assed 48 hours after the electromagnetic exposure. In addition, we have investigated if there are any significant differences between the manner of exposure of $100 \mathrm{~Hz}$ ELF (continuous or discontinuous) and the magnitude of the effects. The use of the COMET assay is a very valuable tool in the identification of possible genotoxic effects of different agents and could offer rapid and solid evidence about the possible impairments of the DNA integrity. Also, this test was used extensively in a study concerning the effect of different types of electromagnetic fields upon the DNA integrity [4].

The qualitative analysis of the comet assay showed a reduction of the frequency of cells with broken DNA between $5-40 \%$, but a significant increase in frequency of the cells with major impairments of the DNA. The late determination of the cells status (48 hours after the treatment) showed that the exposure to the electromagnetic field determined a spectrum of consequences upon the integrity of genetic material, such as damages which activated internal control systems of the cell and the restoration of the normal state of DNA molecule and alterations that couldn't be corrected or needing a longer time to be repaired. The activation of the repairing systems allowed the correction of the errors with a higher efficiency than in the unexposed cells. Nevertheless, the increased frequency of the cells with a high degree of damaged

Table 3 Cell cycle distribution in Vero cells exposed to ELF-EMF

\begin{tabular}{llll}
\hline & \multicolumn{2}{l}{ Cell cycle distribution (\%) } & \\
\cline { 2 - 4 } & G0/G1 stage & S stage & G2/M stage \\
\hline Control cells & 74.94 & 6.01 & 18.86 \\
\hline CEMF & $58.74^{*}(-21.62 \%)$ & $22.42^{* * *}(+273.04 \%)$ & $18.68(-0.95 \%)$ \\
\hline
\end{tabular}

Data are means of three experiments, SD being $>15 \%$. The CV of the peaks were $>8 \%$.

${ }^{*} p<0.05 ;{ }^{* * *} p<0.001$ by Student's t test. 
DNA indicates heterogeneity of cellular response to the electromagnetic field, depending on the cellular state in the moment of exposure. The cell cycle analysis of the exposed cells revealed a blockage of the cells in the $S$ phase of the cell cycle, suggesting that the $100 \mathrm{~Hz}$ ELF could impair the synthetic and correction mechanisms, as was suggested by [27]. In addition, the stop of the cells in S phase of the cell cycle suggests the formation of the single strand breaks or collapse of the DNA replication forks during the $\mathrm{S}$ phase, under the action of the electromagnetic treatment [28]. It is not clear whether the action of the electromagnetic fields is due to a direct or indirect effect, mediated by other mechanisms, as the production of reactive species of oxygen. Some results support redox-mediated ELF-EMF biological effects, as a positive modulation of antioxidant defences was observed, as well as a shift of cellular environment towards a more reduced state [29].

Our data correlates with those obtained by Wolf et al. [30], which signalled that ELF of $50 \mathrm{~Hz}$ determined a transient blockage of the cells in the $\mathrm{S}$ phase of the cell cycle and suggested the implication of the presence of reactive species of oxygen. The data obtained by qualitative evaluation of the cells assessed by comet assay were reinforced by quantitative appreciation of the electromagnetic fields effects. All four parameters determined by us showed an increase in the tail length and the quantity of fragmented DNA in the tail, tail moment and Olive tail moment. The overall evaluation of our findings is that extremely low frequency electromagnetic field acts as a moderate damaging agent. They are in accordance with other studies which suggested the mild oxidative effects of extremely low frequency electromagnetic fields responsible for the DNA damage [31].

Albeit it was signalled that the intermittent exposure showed a stronger effect in the comet assay than continuous exposure [21,32], our results did not find significant differences between the two ways of exposure. The lack of any significant differences between continuous and discontinuous exposure of the cells to ELF-EMF, in our experimental setup, resides in the triggering changes in the metabolic pattern of the used cells, dependent by intensity of the magnetic field and not by the frequency. The modifications induced by ELF-EMF to DNA and their persistence are, most probably, the result of the appearance of the reactive species of oxygen and the prolongation of their lifetime extension under the influence of the magnetic field, as documented by [33]

\section{Conclusions}

The analysis of the registered comet indices and of cell cycle showed that extremely low frequency electromagnetic field of $100 \mathrm{~Hz}$ and $5.6 \mathrm{mT}$ had a genotoxic impact on Vero cells.
The persistence of the errors, even 48 hours after the exposure, indicated the persistence of reactive oxygen species, the perturbation of the cellular apparatus implied in the verification and repairing of the DNA errors and the occurrence of the SSBs in exposed cells.

\section{Abbreviations \\ DMEM: Dulbeco's modified eagle's medium; DNA: Deoxyribonucleic acid ELF-EMF: Extremely low frequency- electromagnetic fields; FBS: Foetal bovine serum; IARC: International agency for research on cancer; NIM-DAPI: Nuclear isolation medium - DAPI, 4',6-diamidino-2-phenylindole; OTM: Olive tail moment; PBS: Phosphate buffered saline; PDC: Pulsating direct current; SD: Standard deviation; SEM: Standard error of mean; SSBs: Single strand breaks; TD: \%DNA in tail; TL: Tail length; TM: Tail moment.}

\section{Competing interests}

The authors declare that they have no competing interests.

\section{Authors' contributions}

MCT carried out the design of the experiment, Comet assay, cell cycle analysis and drafted the manuscript. GV participated at the cell cycle analys, Comet assay and performed the images analysis. FB performed the measurments of the electromagnetic generated field and the software simulation of the magnetic distribution. PR participated in the design of the experiment and in the drafting of the manuscript. All authors read and approved the final manuscript.

\section{Acknowledgements}

This study was possible with financial support from the Sectoral Operational Programme for Human Resources Development, project "Developing the innovation capacity and improving the impact of research through post-doctoral programmes", POSDRU/89/1.5/S/49944

\section{Author details}

'Department of Biology, "Alexandru loan Cuza" University of lasi, lasi, Romania. ${ }^{2}$ National Institute of Research and Development for Biological Sciences, branch Institute of Biological Research lasi, lasi, Romania. ${ }^{3}$ Faculty of Physics, "Alexandru loan Cuza" University of lasi, lasi, Romania.

Received: 20 February 2013 Accepted: 10 November 2013 Published: 8 January 2014

References

1. Tell RA, Sias G, Smith J, Sahl J, Kavet R: ELF magnetic fields in electric and gasoline-powered vehicles. Bioelectromagnetics 2012, 34(2):1-6.

2. Wen J, Jiang $S$, Chen $B$ : The effect of $100 \mathrm{~Hz}$ magnetic field combined with X-ray on hepatoma-implanted mice. Bioelectromagnetics 2011 32(4):322-324.

3. Vijayalaxmi, Obe G: Controversial cytogenetic observations in mammalian somatic cells exposed to extremely low frequency electromagnetic radiation: a review and future research recommendations. Bioelectromagnetics 2005, 26(5):412-430.

4. Phillips JL, Singh NP, Lai H: Electromagnetic fields and DNA damage. Pathophysiol: Official J Int Soc Pathophysiol/ISP 2009, 16(2-3):79-88.

5. IARC Working Group on the Evaluation of Carcinogenic Risks to Humans: International agency for research on cancer IARC monographs on the evaluation of carcinogenic risks to humans. larc Monogr Eval Carcinog Risks Hum 2002, 80:273-338.

6. Hanahan D, Weinberg RA: Hallmarks of cancer: the next gen ration. Cell 2011, 144(5):646-674.

7. Hursting SD, Slaga TJ, Fischer SM, DiGiovanni J, Phang JM: Mechanismbased cancer prevention approaches: targets, examples, and the use of transgenic mice. J Nat Cancer Inst 1999, 91(3):215-225.

8. Devi P: Basics of carcinogenesis. Health Adm 2004, 17:16-24.

9. Khan N, Afaq F, Mukhtar H: Apoptosis by dietary factors: the suicide solution for delaying cancer growth. Carcinogenesis 2007, 28(2):233-239.

10. Blumenthal NC, Ricci J, Breger L, Zychlinsky A, Solomon H, Chen GG, Kuznetsov D, Dorfman R: Effects of low-intensity AC and/or DC 
electromagnetic fields on cell attachment and induction of apoptosis. Bioelectromagnetics 1997, 18(3):264-272.

11. Mairs RJ, Hughes K, Fitzsimmons S, Prise KM, Livingstone A, Wilson L, Baig N, Clark AM, Timpson A, Patel G, Folkard M, Angerson WJ, Boyd M: Microsatellite analysis for determination of the mutagenicity of extremely low-frequency electromagnetic fields and ionising radiation in vitro. Mutat Res 2007, 626(1-2):34-41.

12. Lai $H$, Singh NP: Magnetic-field-induced DNA strand breaks in brain cells of the rat. Environ Health Perspect 2004, 112(6):687-694.

13. Tateno H, lijima S, Nakanishi Y, Kamiguchi Y, Asaka A: No induction of chromosome aberrations in human spermatozoa exposed to extremely low frequency electromagnetic fields. Mutat Res 1998, 414(1-3):31-35.

14. Olsson G, Belyaev IY, Helleday T, Harms-Ringdahl M: ELF magnetic field affects proliferation of SPD8/V79 Chinese hamster cells but does not interact with intrachromosomal recombination. Mutat Res 2001 493(1-2):55-66.

15. Chemeris NK, Gapeyev AB, Sirota NP, Gudkova OY, Kornienko NV, Tankanag AV, Konovalov IV, Buzoverya ME, Suvorov VG, Logunov VA: DNA damage in frog erythrocytes after in vitro exposure to a high peak-power pulsed electromagnetic field. Mutat Res 2004, $\mathbf{5 5 8}(1-2): 27-34$

16. Testa A, Cordelli E, Stronati L, Marino C, Lovisolo GA, Fresegna AM, Conti $D$, Villani P: Evaluation of genotoxic effect of low level $50 \mathrm{~Hz}$ magnetic fields on human blood cells using different cytogenetic assays. Bioelectromagnetics 2004, 25(8):613-619.

17. Zhijian C, Xiaoxue L, Yezhen L, Shijie C, Lifen J, Jianlin L, Deqiang L, Jiliang $\mathrm{H}$ : Impact of $1.8-\mathrm{GHz}$ radiofrequency radiation (RFR) on DNA damage and repair induced by doxorubicin in human B-cell lymphoblastoid cells. Mutat Res 2010, 695(1-2):16-21.

18. Shupak NM, Prato FS, Thomas AW: Therapeutic uses of pulsed magnetic field exposure: a review. Radio Sci Bull 2003, 1(307):9-32.

19. Ostling O, Johanson KJ: Microelectrophoretic study of radiation-induced DNA damages in individual mammalian cells. Biochem Biophys Res Commun 1984, 123:291-298.

20. Singh NP, McCoy MT, Tice RR, Schneider EL: A simple technique for quantitation of low levels of DNA damage in individual cells. Exp Cell Res 1988, 175:184-191.

21. Ivancsits S, Diem E, Jahn O, Rüdiger HW: Intermittent extremely low frequency electromagnetic fields cause DNA damage in a dose-dependent way. Int Arch Occup Environ Health 2003, 76(6):431-436.

22. Vilhar B: Help! There is a comet in my computer! A dummy's guide to image analysis used in the comet assay. http://www.botanika. biologija.org/exp/comet/Comet-principles.pdf.

23. Kumaravel TS, Vilhar B, Faux SP, Jha AN: Comet assay measurements: a perspective. Cell Biol Toxicol 2009, 25:53-64.

24. Diem E, Ivancsits S, Rüdiger HW: Basal levels of dna strand breaks in human leukocytes determined by comet assay. J Toxicol Environ Health Part A 2002, 65(9):641-648.

25. Ivancsits S, Pilger A, Diem E, Jahn O, Rüdiger HW: Cell type-specific genotoxic effects of intermittent extremely low-frequency electromagnetic fields. Mutat Res 2005, 583(2):184-188.

26. Crumpton MJ, Collins AR: Are environmental electromagnetic fields genotoxic? DNA Repair 2004, 3(10):1385-1387.

27. Miyakoshi J, Yoshida M, Shibuya K, Hiraoka M: Exposure to strong magnetic fields at power frequency potentiates $\mathrm{X}$-ray-induced DNA strand breaks. J Radiat Res 2000, 41(3):293-302.

28. Caldecott KW: Single-strand break repair and genetic disease. Nat Rev Genet 2008, 9(8):619-631.

29. Falone S, Grossi MR, Cinque B, D'Angelo B, Tettamanti E, Cimini A, Di llio C, Amicarelli F: Fifty hertz extremely low-frequency electromagnetic field causes changes in redox and differentiative status in neuroblastoma cells. Int J Biochem Cell Biol 2007, 39(11):2093-106.

30. Wolf Fl, Torsello A, Tedesco B, Fasanella S, Boninsegna A, D'Ascenzo M, Grassi C, Azzena GB, Cittadini A: 50-Hz extremely low frequency electromagnetic fields enhance cell proliferation and DNA damage: possible involvement of a redox mechanism. Biochim Biophys Acta 2005, 1743(1-2):120-9.

31. Bułdak RJ, Polaniak R, Bułdak L, Zwirska-Korczala K, Skonieczna M, Monsiol A, Kukla M, Duława-Bułdak A, Birkner E: Short-term exposure to
$50 \mathrm{~Hz}$ ELF-EMF alters the cisplatin-induced oxidative response in AT478 murine squamous cell carcinoma cells. Bioelectromagnetics 2012, 33(8):641-651.

32. Diem E, Schwarz C, Adlkofer F, Jahn O, Rüdiger H: Non-thermal DNA breakage by mobile-phone radiation $(1800 \mathrm{MHz})$ in human fibroblasts and in transformed GFSH-R17 rat granulosa cells in vitro. Mutat Res 2005, 583(2):178-183.

33. Simkó M, Mattsson MO: Extremely low frequency electromagnetic fields as effectors of cellular responses in vitro: possible immune cell activation. J Cell Biochem 2004, 93:83-92.

\section{doi:10.1186/2052-336X-12-15}

Cite this article as: Mihai et al.: Extremely low-frequency electromagnetic fields cause DNA strand breaks in normal cells. Journal of Environmental Health Science \& Engineering 2014 12:15.

\section{Submit your next manuscript to BioMed Central and take full advantage of:}

- Convenient online submission

- Thorough peer review

- No space constraints or color figure charges

- Immediate publication on acceptance

- Inclusion in PubMed, CAS, Scopus and Google Scholar

- Research which is freely available for redistribution
Biomed Central 